\title{
Urinary tract infection attributed to Escherichia coli isolated from participants attending an unorganized gathering
}

\author{
Kamelia M Osman*,1, Anthony D Kappell ${ }^{2}$, Fatma ElHofy ${ }^{3}$, Ahmed Orabi ${ }^{1}$, Ayman S \\ Mubarak $^{4}$, Turki M Dawoud ${ }^{4}$, Ihab MI Moussa ${ }^{4}$ \& Ashgan M Hessain ${ }^{5}$ \\ ${ }^{1}$ Department of Microbiology, Faculty of Veterinary Medicine, Cairo University, Giza, 12211, Egypt \\ ${ }^{2}$ Department of Civil, Construction \& Environmental Engineering, Marquette University, Milwaukee, WI 53233, USA \\ ${ }^{3}$ Department of Bacteriology, Immunology \& Mycology, Faculty of Veterinary Medicine, Moushtohor, Benha University, \\ 13511, Egypt \\ ${ }^{4}$ Department of Botany \& Microbiology, College of Science, King Saud University, Riyadh, 11495, Kingdom of Saudi Arabia \\ ${ }^{5}$ Department of Health Science, College of Applied Studies \& Community Service, King Saud University, Riyadh, 11495, Kingdom \\ of Saudi Arabia \\ *Author for correspondence: kamelia-osman@hotmail.com
}

Aim: Participants in an unorganized gathering are potential hosts of diseases, bringing diseases from around the world to be introduced to a large at-risk population. Therefore, we investigated the gene repertoire in 29 Escherichia coli strains linked to urinary tract infection isolated from patients transferred to the hospital after attending an unorganized gathering in Cairo. Materials \& methods: Virulence and resistance determinants, phenotypic antibiotic resistance, biofilm formation, their serotypes and phylogenetic relationships were analyzed. Results: The 29 tested serovars were phenotypically virulent, with the prevalence of group B2, and resistant to tetracycline, naldixic acid, ampicillin, trimethoprim, neomycin, oxytetracycline and erythromycin encoding the iss virulent gene. Conclusion: A One Health approach is a must to monitor and control $E$. coli urinary tract infections.

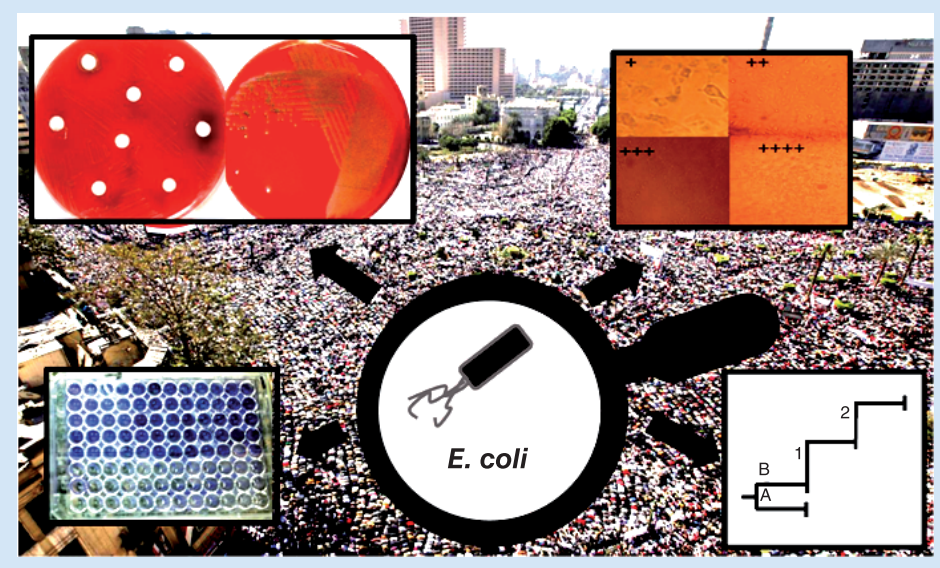

First draft submitted: 21 December 2017; Accepted for publication: 22 February 2018; Published online: 31 May 2018

Keywords: antibiotic resistance genes $\bullet$ biofilm • Egypt $\bullet$ Escherichia coli $\bullet$ UTI $\bullet$ virulence genes

Every year, millions of people travel internationally for either spontaneous or preplanned mass gatherings (MGs) that range from major sports events to fairs, festivals, concerts, religious and educational activities and political rallies [1,2]. Previous reports suggested that the MG can include as few as 1000 people or more than 25,000 
people [3]. This definition might not express an accurate estimation, as the main scenario evident on the ground is a consequence of sudden population displacement. Supermarkets, airports, seaports, malls, and trading centers where more than 100,000 people are coming in and out on a daily basis with minimal stress have been implicated to be ideal locations for the definition of MGs $[1,4,5]$. These locations are ideal for the study of MGs because there are a large number of attendees gathered at a specific site, for a specific occasion or reason, and usually a known duration, and there is potential to overextend local resources[1]. These situations of MGs create an unmatched menace to the escalation of zoonotic diseases $[4,5]$.

In an estimated 14 out of 21 documented events, long-distance spread has repeatedly originated at international MGs by participants traveling back to their home country [6]. Zoonotic infections are documented infectious disease threats to public health, and are associated with MGs globally [7]. A report by the European Centre for Disease Prevention and Control included studies on several disease outbreaks caused by bacterial and viral pathogens during MGs such as at football Euro and World Cups, Olympic and Paralympic Games and religious festivals, including an outbreak of Escherichia coli O157 at a rock festival in the south west of England [8].

In addition to the microbiological risks, antimicrobial resistance (AMR) is aggravated by the unpremeditated dispersion of resistant bacteria globally through traveling, and recently through MGs [9]. The European Centre for Disease Prevention and Control expressed their great concern [8] for the travelers attending the 2016 Olympics and Paralympics Summer Games in Rio de Janeiro, Brazil, regarding the risk of colonization of multi-drug resistance (MDR) Enterobacteriaceae. Yet no study was recorded with respect to this concern, giving the current study its novelty in being the first that gave this matter of the risk of the dispersion of MDR E. coli during an MG the importance of an investigation.

Therefore, we pursued the present study to investigate MDR E.coli using molecular and epidemiological characterization methods including: prevalence, phylogenetic relationships, virulence factors, and AMR genes. This study became the first investigation of its kind globally, as it took place in Egypt during the 2011 MG where hundreds of thousands of protestors had a continuous presence in Al Tahrir square for months, living their lives in tents or directly under the sky; eating, chatting, praying, selling, and so forth, but, most importantly, practicing prefiguration. During this period, El-Tahrir square assumed the form of a giant protest camp setting, carrying on living its own self-sustainable life, where street-stores and merchants were quite prominent. Protesters from all walks of life were scattered across the square: from street vendors selling sandwiches, pastries, and hot and cold drinks, to protesters, farmers, and hijab-wearing women, to young children, university students, and tourists. Even marriage ceremonies were performed. The square became a real city within a city with its own rules, codes, and infrastructure, including tents, clinics and all kinds of food and drink premises. It was without any medical and health professionals, veterinarians, food safety specialists or other experts to monitor and control diseases and infections, including E. coli, a common GI and urinary tract infection (UTI).

\section{Materials \& methods}

Origin \& characteristics of the bacterial strains studied \& ethics statement

Kasr AlAini is a research and teaching hospital in Cairo, Egypt. This hospital is affiliated with the Faculty of Medicine, University of Cairo, with a capacity of more than 5200 beds and growing, in addition to 35 sections in different medical specializations. It is located $2.2 \mathrm{~km}$ south of El-Tahrir Square, the core of the MGs during 26 January 2011 to 31 March 2011 and where male patients with UTIs (i.e., > 1 of the following symptoms: frequent urination; painful urination; hematuria; cloudy urine; or pain in pelvic area, flank, or low back and fever) were sent to the outpatient clinic for sample collection and isolation of E. coli in the Clinical Microbiology Laboratory (CML) of the hospital. A midstream urine capture at the hospital from patients with uncomplicated UTIs was immediately cultured after collection. The 29 clinical E. coli isolates in this study were re-identified by using the API 20E system (bioMérieux SA, Marcy l'Etoile, France). The E. coli included in the study were from cultures yielding $>10^{5} \mathrm{CFU} / \mathrm{ml}$. The 29 clinical $E$. coli isolates had an instantaneous and overnight investigation for their phenotypic AMR. All isolates were propagated aerobically at $35^{\circ} \mathrm{C}$ in Luria-Bertani (LB) broth or on LB agar.

\section{Somatic typing \& expression of phenotypic virulence markers}

The 29 available human E. coli isolates were tested for their pathogenicity [10]. Classical tests for E. coli pathogenicity included motility, hemolysin production, and Congo red uptake to differentiate between the virulent and avirulent E. coli isolates, assessment of chick embryo mortality (for infection, $\sim 2 \times 107 \mathrm{CFU} / 0.1 \mathrm{ml}$ E. coli) and detection of cytotoxic activity on Vero cell monolayers and MDCK (Madin-Derby Canine Kidney) cells (for infection, 


\begin{tabular}{|c|c|c|c|c|}
\hline Gene targeted & Amplicon size (bp) & Primer sequences $\left(5^{\prime}-3^{\prime}\right)$ & Function & Ref. \\
\hline \multicolumn{5}{|c|}{ Primers for phylogenetic analysis } \\
\hline \multirow[t]{2}{*}{ chuA } & 279 & F- GACGAACCAACGGTCAGGAT & Heme transport & [13] \\
\hline & & R- TGCCGCCAGTACCAAAGACA & & \\
\hline \multirow[t]{2}{*}{ YjaA } & 211 & F- TGAAGTGTCAGGAGACGCTG & Uncharacterized function & \\
\hline & & R- ATGGAGAATGCGTTCCTCAAC & & \\
\hline \multirow[t]{3}{*}{ TspE4.C2 } & 152 & F- GAGTAATGTCGGGGCATTCA & Anonymous DNA fragment & \\
\hline & & R- CGCGCCAACAAAGTATTACG & & \\
\hline & & R- CTA TTG TGA GCA ATA TAC CC & & \\
\hline \multicolumn{5}{|c|}{ Primers used for drug resistance genes } \\
\hline \multirow[t]{2}{*}{$\operatorname{tet}(A)$} & 888 & F- GTGAAACCCAACATACCCC & Tetracycline resistance & [20] \\
\hline & & R- GAAGGCAAGCAGGATGTAG & & \\
\hline \multirow[t]{2}{*}{$d h f r l$} & 391 & F- AAGAATGGAGTTATCGGGAATG & Trimethoprim resistance & \\
\hline & & R- GGGTAAAAACTGGCCTAAAATTG & & \\
\hline \multirow[t]{2}{*}{ dhfrV } & 432 & F- CTGCAAAAGCGAAAAACGG & & \\
\hline & & R- AGCAATAGTTAATGTTTGAGCTAAAG & & \\
\hline \multirow[t]{2}{*}{ dhfrXIII } & 294 & F- CAGGTGAGCAGAAGATTTTT & & \\
\hline & & R- CCTCAAAGGTTTGATGTACC & & \\
\hline \multirow[t]{2}{*}{ sull } & 822 & F- TTCGGCATTCTGAATCTCAC & Sulphonamide resistance & \\
\hline & & R- ATGATCTAACCCTCGGTCTC & & \\
\hline \multirow[t]{2}{*}{ sullI } & 722 & F- CGGCATCGTCAACATAACC & & \\
\hline & & R- GTGTGCGGATGAAGTCAG & & \\
\hline
\end{tabular}

$\sim 2 \times 107 \mathrm{CFU} / 0.1 \mathrm{ml}$ ). E. coli $\mathrm{J} 96$ (for hemolysin production), EHEC strain EDL 933 (for chick embryo lethality and cytotoxic activity) were used as positive controls. E. coli K-12 and E. coli DH5 $\alpha$ were also used as a negative control in the chick embryo lethality and cytotoxic activity tests.

Serotyping of the $E$. coli isolates were performed by the agglutination test using commercially available O-antisera (Denka Seiken Co. Ltd., Tokyo, Japan).

\section{Antimicrobial susceptibility testing}

The 29 purified isolates were subjected to a panel of 15 antibiotic discs for the antimicrobial susceptibility testing. The antibiotic discs used were: nalidixic acid, tetracycline, doxycycline, gentamicin, neomycin, norfloxacin, ciprofloxacin, chloramphenicol, colistin sulphate, ampicillin, oxytetracycline, streptomycin, erythromycin, trimethoprim and sulphamethoxazole trimethoprim. Resistance was determined according to the interpretative standards of CLSI [11] against an E. coli standard (ATCC No. 25922).

\section{Biofilm formation assay}

Biofilm formation by E. coli was assayed by the two classical methods as previously described [12]. For biofilm analysis, $1 \times 10^{7} \mathrm{CFU}$ of $E$. coli in $100 \mu \mathrm{l}$ of LB broth $\left(1 \times 10^{8} \mathrm{CFU} / \mathrm{ml}\right)$ was inoculated into the wells of a 96-well flat-bottom polystyrene microtiter plate grown at $37^{\circ} \mathrm{C}$ for $48 \mathrm{~h}$ and the attached biofilms were stained with $0.1 \%$ crystal violet and the absorbance was measured at $\mathrm{OD}_{595}$ using a microplate reader. On the other hand, a visible film lining the wall and the bottom of the borosilicate tubes is consistent with biofilm formation and the degree of biofilm formed was evaluated as $1=$ weak/none, $2=$ moderate and $3=\mathrm{high} / \mathrm{strong}$. The reference strain of positive biofilm producer E. coli ATCC 35218 was used as control.

\section{Phylogenetic classification}

The phylogeny of the 29 E. coli isolates was determined as detailed in Table 1. E. coli ATCC 25922 was used as positive PCR control. 
DNA preparation \& identification of the genes associated with virulence \& antibiotic resistance DNA for template in PCR reactions were generated using cell pellets from $100 \mu \mathrm{l}$ of an overnight culture containing the $E$. coli isolates in LB broth (Difco) with constant shaking at $37^{\circ} \mathrm{C}$. The pellets were resuspended in moleculargrade nuclease-free water and incubated at $95^{\circ} \mathrm{C}$ for $20 \mathrm{~min}$. The lysates were centrifuged at $2000 \times g$ for $5 \mathrm{~min}$ and the supernatants were frozen for use in PCR.

The isolates were tested for six different antibacterial resistant genes [tet(A), dhfrI, dhfrV, dhfrXIII, sulI and sulII] using a multiplex PCR-based assay (Table 1) using the conditions specified for each primer.

The $50 \mu \mathrm{l}$ PCR reactions were performed with $3 \mu \mathrm{l}$ of bacterial lysate, $5 \mu \mathrm{l}$ of $10 \times$ primer mix, $25 \mu \mathrm{l}$ of GoTaq Colorless Master Mix (Promega Corporation, WI, USA), and the remain volume with molecular-grade nuclease-free water. The isolates were additionally examined for the presence of eight virulence genes (uidA, pap $\mathrm{C}$, iroN $N_{\text {E. coli, }}$ kps MT II, ompA, ibeA, eaeA and iss) by PCR amplification. The primer sets and PCR conditions were used as previously described and indicated in Table 2. The $50 \mu \mathrm{l}$ 'hot start' method PCR reactions consisted of $10 \mu \mathrm{l}$ of template DNA, $5 \mu \mathrm{M}$ of primers, $25 \mathrm{mM} \mathrm{MgCl}, 10 \mathrm{mM}$ dNTPs, $23 \mathrm{ng}$ BSA, 1.25 U Taq DNA polymerase (Sigma, MO, USA), and the remaining volume with molecular-grade nuclease-free water. Amplified products were analyzed by $2 \%$ agarose gel electrophoresis stained with ethidium bromide. Positive control strains of E. coli containing genes used in this study included: E. coli ATCC 8739, DSM 4618, DSM 8695, ATCC 10798, ATCC 67973, ATCC 77379, E. coli 2363, ATCC 69119, ATCC 87386 and ATCC 86980. A negative reagent control consisted of the PCR buffer and nuclease-free water were used.

\section{Sequencing reaction $\&$ genetic analysis}

Purification of the PCR products was carried out using QIAquick Gel Extraction kit (Qiagen, GmbH, Hilden, Germany) using Big dye Terminator V3.1 cycle sequencing kit (Perkin-Elmer, CA, USA, cat-number 4336817) according to the instruction of the manufacturer as follows. The $20 \mu \mathrm{l}$ consists of: $2 \mu \mathrm{l}$ Big dye terminator v.3.1, $1 \mu \mathrm{l}$ primer, $1-10 \mu \mathrm{l}$ template according to quality of band and concentration of DNA, complete to total volume of $20 \mu \mathrm{l}$ with PCR grade water. Performing gene sequencing was carried out using an Applied Biosystems 3130 genetic analyzer (Hitachi, Japan). For sequence analysis the Bioedit software was used to analyze the sequence of $\mathrm{M}$ gene of the isolates in this study. For Phylogenetic analysis the DNAstar MegAlign software was used for the alignment for the $\mathrm{M}$ sequence and phylogenetic analysis for these isolates using Clustal V method. Sequence distance was calculated to display the divergence and identity percent values of each sequence pair. The software MegAlign calculates divergence in relation to the phylogeny reconstructed between sequence pairs and percent identity compares sequence pairs directly excluding phylogenetic relationships. Calculated Residue Substitutions by MegAlign software predicted to have occurred to give rise to the sequence differences in the current alignment. The table may be useful in identifying unusual patterns of substitutions.

\section{Results}

Phenotypic virulence factors

Results included the identification of $E$. coli phylogenetic groups, serovar distribution and associated virulence genes combinations isolated during the MG in El-Tahrir Square between 2011 and 2013. Congo red assay was used as a phenotypic marker for the invasive and noninvasive E. coli. In the present study, all of the 29 tested serovars for the CR-binding affinities were $100 \%$ positive, although binding activity varied according to serotypes. The isolates were also able to produce cytopathic effects on the Vero and MDCK cells and had $100 \%$ motility, embryo lethality as well as hemolytic activity.

\section{Distribution of phenotypic resistance to individual antimicrobial agents}

The results of testing the AMR of the 29 E. coli isolates recovered from human samples, indicated that 29 out of 29 isolates $(100 \%)$ were resistant to tetracycline, naldixic acid, ampicillin, trimethoprim, neomycin, oxytetracycline and erythromycin. On the other hand, only five out of 29 (17.2\%) were resistant to colistin (Table 3). In other words, 24 isolates were susceptible to colistin.

\section{Prevalence of phylogenetic groups}

Our phylogenetic analysis identified different pathotypes. Three phylogenetic groups were recovered (Table 4). The distribution of the 29 E. coli strains among the three phylogenetic groups was B2 ( $\mathrm{n}=13 / 29,44.8 \%)$, followed by 
Table 2. List of PCR targets with primers sequences for E.coli virulence gene amplification.

\begin{tabular}{|c|c|c|c|c|c|c|c|}
\hline Target gene & Function & Pathotype & bp & & Primer sequence & Cycling conditions & Ref. \\
\hline \multirow[t]{3}{*}{$\begin{array}{l}\text { uidA } \\
\text { gene of } E \text {. coli } \\
\text { (Encodes GUS } \\
\text { ( } \beta \text {-D- } \\
\text { glucuronidase) } \\
\text { protein) }\end{array}$} & $\begin{array}{l}\text { Encodes for } \\
\text { b-D-glucuronidase }\end{array}$ & EHEC & 468 & $\mathrm{~F}$ & 5' ATC ACC GTG GTG ACG CATGTC GC 3 & $\begin{array}{l}95^{\circ} \mathrm{C} \text { for } 5 \mathrm{~min} \\
\text { Amplification ( } 35 \text { cycles of) } \\
95^{\circ} \mathrm{C} \text { for } 30 \mathrm{~s} \\
50^{\circ} \mathrm{C} \text { for } 1 \mathrm{~min} \\
72^{\circ} \mathrm{C} \text { for } 1 \mathrm{~min} \\
\text { final extension } \\
72^{\circ} \mathrm{C} \text { for } 5 \mathrm{~min}\end{array}$ & [14] \\
\hline & & & & $\mathrm{R}$ & $5^{\prime}$ CAC CAC GAT GCC ATG TTC ATCTGC $3^{\prime}$ & & \\
\hline & & & & $\mathrm{R}$ & 5' CTA TTG TGA GCA ATA TAC CC 3' & & \\
\hline \multirow[t]{2}{*}{$\begin{array}{l}\text { papC } \\
\text { Chaperon usher } \\
\text { protein } \\
\text { pyelonephritis- } \\
\text { associated } \\
\text { pili }\end{array}$} & $\begin{array}{l}\text { Pilus associated with } \\
\text { pyelonephritis }\end{array}$ & UPEC & 501 & $\mathrm{~F}$ & 5' TGATATCACGCAGTCAGTAGC $3^{\prime}$ & $\begin{array}{l}94^{\circ} \mathrm{C} \text { for } 3 \mathrm{~min} \\
\text { Amplification ( } 30 \text { cycles of) } \\
94^{\circ} \mathrm{C} \text { for } 1 \mathrm{~min} \\
58^{\circ} \mathrm{C} \text { for } 30 \mathrm{~s} \\
68^{\circ} \mathrm{C} \text { for } 3 \mathrm{~min} \\
\text { final extension } \\
72^{\circ} \mathrm{C} \text { for } 10 \mathrm{~min}\end{array}$ & [15] \\
\hline & & & & $\mathrm{R}$ & $5^{\prime}$ CCGGCCATATTCACATAAC $3^{\prime}$ & & \\
\hline \multirow[t]{2}{*}{$\begin{array}{l}\text { iro } N_{E . c o l i} \\
\text { a Catecholate } \\
\text { siderophore } \\
\text { (salmochelin) } \\
\text { receptor }\end{array}$} & $\begin{array}{l}\text { Catecholatesiderophore } \\
\text { (salmochelin) receptor }\end{array}$ & UPEC & 847 & $\mathrm{~F}$ & 5' ATCCTCTGGTCGCTAACTG $3^{\prime}$ & - & [16] \\
\hline & & & & $\mathrm{R}$ & 5' CTGCACTGGAAGAACTGTTCT 3' & & \\
\hline \multirow[t]{2}{*}{$\begin{array}{l}\text { kpsMT II } \\
\text { Group II capsule } \\
\text { antigens }\end{array}$} & Group II capsule antigens & MNEC & 280 & $\mathrm{~F}$ & 5' CAGGTAGCGTCGAACTGTA 3' & $\begin{array}{l}94^{\circ} \mathrm{C} \text { for } 3 \mathrm{~min} \\
\text { Amplification ( } 30 \text { cycles of) } \\
94^{\circ} \mathrm{C} \text { for } 1 \mathrm{~min} \\
54^{\circ} \mathrm{C} \text { for } 30 \mathrm{~s} \\
68^{\circ} \mathrm{C} \text { for } 3 \mathrm{~min} \\
\text { final extension } \\
72^{\circ} \mathrm{C} \text { for } 10 \mathrm{~min}\end{array}$ & [17] \\
\hline & & & & $\mathrm{R}$ & $5^{\prime}$ CATCCAGACGATAAGCATGAGCA $3^{\prime}$ & & \\
\hline \multirow[t]{2}{*}{$\begin{array}{l}\text { ompA } \\
\text { Outer } \\
\text { membrane } \\
\text { protein }\end{array}$} & Outer membrane protein & MNEC, EHEC & 919 & $\mathrm{~F}$ & 5' AGCTATCGCGATTGCAGTG 3' & $\begin{array}{l}94^{\circ} \mathrm{C} \text { for } 3 \mathrm{~min} \\
\text { Amplification ( } 30 \text { cycles of) } \\
94^{\circ} \mathrm{C} \text { for } 1 \mathrm{~min} \\
58^{\circ} \mathrm{C} \text { for } 30 \mathrm{~s} \\
68^{\circ} \mathrm{C} \text { for } 3 \mathrm{~min} \\
\text { final extension } \\
72^{\circ} \mathrm{C} \text { for } 10 \mathrm{~min}\end{array}$ & [16] \\
\hline & & & & $\mathrm{R}$ & 5' GGTGTTGCCAGTAACCGG 3' & & \\
\hline \multirow[t]{2}{*}{$\begin{array}{l}\text { ibeA } \\
\text { Invasion of brain } \\
\text { endothelium }\end{array}$} & Invasion of brain endothelium & MNEC & 342 & $\mathrm{~F}$ & 5' TGGAACCCGCTCGTAATATAC $3^{\prime}$ & - & [16] \\
\hline & & & & $\mathrm{R}$ & 5' CTGCCTGTTCAAGCATTGCA 3' & & \\
\hline \multirow[t]{2}{*}{$\begin{array}{l}\text { eaeA } \\
\text { En- } \\
\text { teropathogenic } \\
\text { attachment and } \\
\text { effacement }\end{array}$} & $\begin{array}{l}\text { Enteropathogenic attachment } \\
\text { and effacement }\end{array}$ & EPEC/EHEC & 384 & $\mathrm{~F}$ & $5^{\prime}$ GAC CCG GCA CAA GCA TAA GC $3^{\prime}$ & $\begin{array}{l}94^{\circ} \mathrm{C} \text { for } 5 \mathrm{~min} \\
\text { Amplification ( } 35 \text { cycles of) } \\
94^{\circ} \mathrm{C} \text { for } 1 \mathrm{~min} \\
54^{\circ} \mathrm{C} \text { for } 30 \mathrm{~s}, \\
72^{\circ} \mathrm{C} \text { for } 2 \mathrm{~min}, \\
\text { final extension } \\
72^{\circ} \mathrm{C} \text { for } 10 \mathrm{~min}\end{array}$ & [18] \\
\hline & & & & $\mathrm{R}$ & $5^{\prime}$ CCA CCT GCA GCA ACA AGA GG $3^{\prime}$ & & \\
\hline \multirow[t]{2}{*}{$\begin{array}{l}\text { iss } \\
\text { Increased serum } \\
\text { survival gene }\end{array}$} & Increased serum survival gene & EXPEC & 266 & $\mathrm{~F}$ & 5' ATG TTA TTT TCT GCC GCT CTG 3' & - & [19] \\
\hline & & & & $\mathrm{R}$ & $5^{\prime}$ CTA TTG TGA GCA ATA TAC CC $3^{\prime}$ & & \\
\hline
\end{tabular}

A $(n=10 / 29,34.5 \%)$ and D $(n=5 / 29,17.2 \%)$. The phylogenetic group B1, classified as physiological microflora in the GI tract, was not detected.

Prevalence \& combinations of the virulence genes among phylogenetic groups

The $29 \mathrm{E}$. coli isolates screened by PCR analysis indicated that there were three patterns for the distribution of the virulence genes encoding the $E$. coli isolates. A double combination of virulence genes were detected in the form of 
Table 3. Distribution of sero- and phylogenetic groups, biofilm formation, virulence traits and resistance genes among human isolates.

\begin{tabular}{|c|c|c|c|c|c|c|}
\hline \multirow[t]{2}{*}{ Serotypes } & \multirow{2}{*}{$\begin{array}{l}\text { Phylogenetic } \\
\text { groups }\end{array}$} & \multirow[t]{2}{*}{ Biofilm biding activity } & \multirow{2}{*}{$\begin{array}{l}\text { Virulence } \\
\text { genes }\end{array}$} & \multirow[t]{2}{*}{ Resistance genes } & \multicolumn{2}{|l|}{ Antibiotic resistance profile } \\
\hline & & & & & Antibiotics profile & $\begin{array}{l}\text { Total number of } \\
\text { antibiotics }\end{array}$ \\
\hline O44: K74 & B2 & Low glass- low plastic & ompA- iss & tet (A)- dhfrl- dhfrXIII & NA- T- TR- E- N- A- O- SXT- NX- CF- S- DO- G- CL & $14 / 15$ \\
\hline O44: K74 & A & Low glass- low plastic & iss & ND & NA- T- TR- E- N- A- O- SXT- NX & $9 / 15$ \\
\hline O44: K74 & B2 & Low glass- low plastic & iss & sull- sulll & $\begin{array}{l}\text { NA- T- TR- E- N- A- O- SXT- NX- CF- S- DO- C- G- } \\
C L\end{array}$ & $15 / 15$ \\
\hline O44: K74 & A & Low glass- low plastic & iss & sull & NA- T- TR- E- N- A- O- CF- DO- C & $10 / 15$ \\
\hline O44: K74 & A & High glass- High plastic & iss & dhfrl- sull & $\begin{array}{l}\text { NA- T- TR- E- N- A- O- SXT- NX- CF- S- DO- C- G- } \\
\text { CL }\end{array}$ & $15 / 15$ \\
\hline O44: K74 & B2 & Low glass- low plastic & papC-iss & sull-sulll & NA- T- TR- E- N- A- O- SXT- NX- CF- C- G & $13 / 15$ \\
\hline O44: K74 & B2 & High glass- low plastic & iss & tet (A)- dhfrl- dhfrXIII & NA- T- TR- E- N- A- O- SXT- NX- CF- S- DO- G & $13 / 15$ \\
\hline O55:K7 & A & Low glass- low plastic & ompA-iss & dhfrl- sulll & NA- T- TR- E- N- A- O- SXT- NX- S & $10 / 15$ \\
\hline O55:K7 & B2 & Low glass- low plastic & ompA-iss & dhfrl- dhfrXIII- sullI & NA- T- TR- E- N- A- O- SXT- NX- CF- S- DO- C & $13 / 15$ \\
\hline O55:K7 & $\mathrm{D}$ & Low glass- low plastic & iss & sull- sulll & NA- T- TR- E- N- A- O- SXT- NX- CF- S & $11 / 15$ \\
\hline O55:K7 & $\mathrm{D}$ & Low glass- low plastic & papC-iss & dhfrXIII & NA- T- TR- E- N- A- O- SXT- NX- CF- S- DO- C & $13 / 15$ \\
\hline O111:K58 & B2 & Low glass- low plastic & papC- iss & $\begin{array}{l}\text { tet (A)- dhfrl- dhfrXIII- sull- } \\
\text { sullI }\end{array}$ & NA- T- TR- E- N- A- O- SXT- NX- CF- S- DO- C- G & $14 / 15$ \\
\hline 0111: K58 & $\mathrm{D}$ & Low glass- low plastic & iss & $d h f r l$ & NA- T- TR- E- N- A- O- SXT- NX- CF- S- DO- C & $13 / 15$ \\
\hline O114:K90 & A & Low glass- low plastic & ompA-iss & dhfrl- dhfrXIII- sullI & NA- T- TR- E- N- A- O- SXT- NX- S- DO- C- G & $13 / 15$ \\
\hline O114:K90 & B2 & Low glass- low plastic & papC- iss & dhfrl- dhfrXIII & NA- T- TR- E- N- A- O- SXT- NX- S- DO- C- G- CL & $14 / 15$ \\
\hline O114:K90 & B2 & Low glass- low plastic & iss & dhfrl- dhfrXIII- sull- sullI & NA- T- TR- E- N- A- O- SXT- NX- CF- DO- C- G & $13 / 15$ \\
\hline O114:K90 & B2 & Low glass- low plastic & papC- iss & $\begin{array}{l}\text { tet (A)- dhfrl- dhfrXIII- sull- } \\
\text { sullI }\end{array}$ & NA- T- TR- E- N- A- O- SXT- NX- CF- S- DO- C- G & $14 / 15$ \\
\hline O114:K90 & B2 & Low glass- low plastic & iss & dhfrl- dhfrXIII & NA- T- TR- E- N- A- O- SXT- NX- CF- S- DO- G & $13 / 15$ \\
\hline O125:K70 & A & High glass- low plastic & ompA-iss & tet $(A)$ - dhfrl- sulll & NA- T- TR- E- N- A- O- SXT- NX- CF- S & $11 / 15$ \\
\hline O125:K70 & B2 & Low glass- low plastic & iss & dhfrl- dhfrXIII- sull- sullI & NA- T- TR- E- N- A- O- SXT- NX- CF- S- DO- C- G & $14 / 15$ \\
\hline O125:K70 & B2 & Low glass- low plastic & iss & dhfrl- sull- sullI & NA- T- TR- E- N- A- O- SXT- NX- CF- S- DO- C- G & $14 / 15$ \\
\hline 0125: K70 & A & Low glass- low plastic & papC- iss & ND & NA- T- TR- E- N- A- O- SXT- NX- CF- S- DO & $12 / 15$ \\
\hline O125:K70 & A & Low glass- low plastic & papC-iss & ND & NA- T- TR- E- N- A- O- SXT- NX- CF- S- DO- C- G & $14 / 15$ \\
\hline 0125:K70 & A & Low glass- low plastic & iss & tet $(A)$ & NA- T- TR- E- N- A- O- SXT- NX- CF- S- DO- G & $13 / 15$ \\
\hline 0125:K70 & B2 & Low glass- low plastic & iss & tet (A)- dhfrl- sullI & NA- T- TR- E- N- A- O- SXT- NX- CF- C- G- CL & $13 / 15$ \\
\hline 0125:K70 & D & Low glass- low plastic & iss & dhfrl-sull-sulll & NA- T- TR- E- N- A- O- SXT- NX- CF- C & $11 / 15$ \\
\hline Untypable & A & Low glass- low plastic & iss & ND & NA- T- TR- E- N- A- O- SXT- NX- CF- S- DO- C & $13 / 15$ \\
\hline Untypable & B2 & High glass- High plastic & iss & sull- sulll & NA- T- TR- E- N- A- O- SXT- NX- CF- S- DO & $12 / 15$ \\
\hline Untypable & $\mathrm{D}$ & High glass- low plastic & papC-iss & dhfrXIII & NA- T- TR- E- N- A- O- SXT- NX- CF & $10 / 15$ \\
\hline
\end{tabular}

Table 4. Relationship between phylogeny and virulence of $E$. coli isolates.

\begin{tabular}{|c|c|c|c|c|c|c|c|c|}
\hline \multirow{2}{*}{$\begin{array}{l}\text { Phylogenetic } \\
\text { groups }\end{array}$} & \multicolumn{7}{|c|}{ Virulence genes } & \multirow[t]{2}{*}{ Total genes $/ 29$} \\
\hline & ompA & papC & iro $\mathrm{N}_{E . \text { coli }}$ & kpsMT II & iss & eae & ibeA & \\
\hline $\begin{array}{l}\text { A } \\
10 / 29(34.5 \%)\end{array}$ & $3 / 10(30 \%)$ & $2 / 10(20 \%)$ & ND & ND & $10 / 10(100 \%)$ & ND & ND & $15 / 29(51.7 \%)$ \\
\hline $\begin{array}{l}\text { B2 } \\
14 / 29(48.3 \%)\end{array}$ & $2 / 14(14.3 \%)$ & $3 / 14(21.4 \%)$ & ND & ND & $14 / 14(100 \%)$ & ND & ND & $19 / 29(65.5 \%)$ \\
\hline $\begin{array}{l}\text { D } \\
5 / 29(17.2 \%)\end{array}$ & ND & $2 / 5(40 \%)$ & ND & ND & $5 / 5(100 \%)$ & ND & ND & $7 / 29(24.1 \%)$ \\
\hline Total gene & $5 / 29(17.2 \%)$ & $7 / 29(24.1 \%)$ & ND & ND & $29 / 29(100 \%)$ & ND & ND & \\
\hline
\end{tabular}

ND: Not detected. 


\begin{tabular}{|c|c|c|c|c|c|c|}
\hline \multirow[t]{2}{*}{ Antibiotic } & \multirow[t]{2}{*}{ Resistance genes } & \multirow[t]{2}{*}{$\begin{array}{l}\text { Resistant isolates } \\
(n=29)\end{array}$} & \multirow[t]{2}{*}{$\%$ Resistance } & \multicolumn{3}{|c|}{$\begin{array}{l}\text { Phylogenetic grouping of } E \text {. coli isolates, and their resistance, according } \\
\text { to phylogenetic groups }\end{array}$} \\
\hline & & & & Group $A(n=10)$ & Group B2 $(n=14)$ & Group $D(n=5)$ \\
\hline Tetracycline & $\operatorname{tet}(A)$ & 7 & 24.1 & $2(20 \%)$ & $5(35.7 \%)$ & ND \\
\hline \multirow[t]{2}{*}{ Sulphonamide } & sull & 12 & 41.4 & $2(20 \%)$ & $8(57.1 \%)$ & $2(40 \%)$ \\
\hline & sulll & 14 & 48.3 & $3(30 \%)$ & $10(71.4 \%)$ & $2(40 \%)$ \\
\hline Trimethoprim & dhfrXIII & 12 & 41.4 & $1(10 \%)$ & $9(64.3 \%)$ & $2(40 \%)$ \\
\hline
\end{tabular}

iss + omp A genes in five out of 29 isolates (17.2\%), while the two genes pap $\mathrm{C}+i$ iss were detected in seven out of 29 (24.1\%). The iss gene was consistant in all of the $29 \mathrm{E}$. coli isolates (100\%). The distribution of the other virulence genes was as follows: pap C 7/29 (24.1\%) and ompA 5/29 (17.2\%). None of the iro $\mathrm{N}_{E . c o l i}, k p s \mathrm{MT}$ II, ibeA and eae genes were detected in any of the $29 \mathrm{E}$. coli isolates (Tables $3 \& 4$ ).

Table 4 represents the analysis of the virulence factors profiles among the phylogenetic groups of $E$. coli isolates. While the iss gene was detected with the highest prevalence in seropathotypes A, B2 and D (100\%), the eae, ibe A, iro $\mathrm{N}_{E . c o l i}$, and kps $\mathrm{MT}$ II genes were totally absent from the three phylogenetic groups that were identified in the 29 E. coli isolates. It was also observed that the ompA gene was not detected in isolates belonging to phylogenetic group D.

Prevalence \& combinations of the antibiotic resistance genes among seropathotypes

As recorded in Tables $3 \& 5$, the trimethoprim $d h f r V$ gene was not detected in any of the $29 E$. coli isolates. From the 29 E. coli screened isolates, four out of 29 (13.8\%) did not carry any of the six antibiotic resistance genes $($ tet $(A)$, dhfrI, dhfrV, dhfrXIII, sulI and sulII).

Four different antibiotic resistance genes combinations (19/29, 65.5\%) were seen (Table 5) in the form of:

Eight double (eight out of 29, 27.6\%) gene combinations: ( $\mathrm{n}=2 / 29(6.9 \%)$, dhfrI- dhfrXIII; $\mathrm{n}=\mathrm{n}=2 / 29$ (6.9\%), dhfrI- sulI, Trimethoprim + Sulphonamide), $(\mathrm{n}=4 / 29$ (13.8\%), sulI- sulII Sulphonamide), seven triple (seven out of 29, 24.1\%) gene combinations: ( $\mathrm{n}=1(3.5 \%)$, tet $(A)$ - dhfrI- dhfrXIII; $\mathrm{n}=\mathrm{n}=2 / 29(6.9 \%)$, dhfrI- sulIsulII, Trimethoprim + Sulphonamide; $\mathrm{n}=\mathrm{n}=2 / 29$ (6.9\%), dhfrI- dhfrXIII- sulII Trimethoprim + Sulphonamide; $\mathrm{n}=\mathrm{n}=2 / 29(6.9 \%)$, tet $(A)-d h f r I-$ sulII Tetracycline + Trimethoprim + Sulphonamide), two quadruple (two out of 29, 6.9\%) gene combinations: $(\mathrm{n}=\mathrm{n}=2 / 29(6.9 \%)$, dhfrI- dhfrXIII- sulI- sulII Trimethoprim + Sulphonamide) and two pentadruple (two out of 29, 6.9\%) gene combinations: $(\mathrm{n}=\mathrm{n}=2 / 29(6.9 \%)$ tet (A)-dhfrI-dhfrXIII- sulIsulII Tetracycline + Trimethoprim + Sulphonamide).

Our phylogenetic analysis identified different pathotypes. Each pathotype exhibited a unique combination of virulence factors that results in a distinctive pathogenic mechanism. The phylogenetic group $\mathrm{D}$ was observed in $5 \%$ of the human isolates. The relation between phylogenetic group and antibiotic resistance indicated that the isolates belonging to group $\mathrm{D}$ were more related with multiresistance than those belonging to other groups.

\section{Associations between biofilm formation, seropathotypes, virulence \& antibiotic resistance}

Generally, of the 29 E. coli isolates, 21 isolates $(72.4 \%)$ exhibited a weak adherence affinity to a glass and plastic surfaces (Table 3), while only two out of 29 isolates (6.9\%) were high in their affinity for biofilm formation on glass and plastic surfaces. There was no evident special association between biofilm formation affinity, seropathotypes, virulence and antibiotic resistance.

\section{Discussion}

As far as infectious diseases go, the most substantial risk to attendants to MGs would be a gastrointestinal infection. The possibility of exposure to infectious diseases at MGs is substantial and needs to be thoroughly explored after a previous study on the epidemiological situation of E. coli in the same situation, location and periods [10]. Escherichia coli epidemiology has not been explored during MGs and this study viewed the role of gene repertoire in bacterial niche ecology, including the genomic bases of phenotypes that are directly linked with pathogenicity. As far as infectious diseases, the most substantial risk to attendants to MGs would be a gastrointestinal infection. 
People attending MGs potentially bring diseases from their geographical origin and disseminate a disease, potentially rapidly, to other individuals who are at the MG being Nationals or foreigners [9]. Therefore, it should be highlighted as the increased risk of communicable disease transmission are often problematic aspects resulting from sudden population displacement [9]. In 1987, an outbreak of MDR shigellosis affected more than 50\% of the attendees at the annual Rainbow Family Gathering in Nantahala National Forest, NC, USA [21]. The risks associated with MGs and its role in the propagation and dissemination of MDR E. coli could have a devastating effect on the attendees at the MGs. The significant population density confined within the limits of Tahrir Square alongside poor health and community planning services presented several environmental risks. This situation likely generated sanitation, hygiene and environmental problems and altered water accessibility and quality at the local level. Previous risk analysis of MGs and modes of transmission [22] included factors such as close person-to-person contact, age and sex of the participants, number of participants, location, the capacity limit of the location, as well as the source of food, particularly street vendors, as the primary reservoir of $E$. coli. In addition, several other health and exposure factors were examined, such as prospective insect and animal vectors, standard of the water and sanitation resources, the homeless situation, housing (i.e., tents), and environmental conditions such as the cold winter weather which strained the immune system's tolerance to combat infections. Other factors examined in the analysis of MGs and modes of transmission included systemic susceptibilities of the population resulting in contagious or infectious disease outbreaks, including indigenous infectious agents circulating in the general and participating population.

To our knowledge, this is the first study to evaluate the different $E$. coli pathotypes in MGs in Egypt. The E. coli serotypes isolated from our patients attending the unorganized MG revealed serovars O44:K74, O55:K7, 111:K58, O114:K90 and O125:K70 which differed from the previously isolated serovars O164:K, O126:K71 and O86:K61 that were collected and analyzed a year earlier from the same environment [10] reflecting the introduction of new serotypes in the environ of Kasr AlAini Hospital. In the present study, the isolates fell mostly into phylogenetic group B2, which belongs to the virulent pathotype of E. coli [20,23-27], which reflects the risk associated with traveling to attend unorganized or organized MGs. Diversity in the serotypes and phylogenetic analyses identified both in the present investigation, and in previous and coming investigations, reflect the differences between the geographically diverse communities and demographic variables [28,29].

Contributors to the spread of AMR are the physical spread of resistant bacteria during MGs, and the geographical spread of resistant bacteria [9] through MG attendees, who are potentially bringing diseases from their own particular geography and could introduce a disease into the MGs. MDR resistance among E. coli has been reported from different regions of the globe, and the rate of antibiotic resistance is higher in E. coli from recurrent UTIs [30] which has emerged as an important reservoir of resistance to cephalosporins, fluoroquinolones and SXT being the first-line antibiotics by the international clinical practice guidelines [31]. The percentages of $E$. coli strains resistant to sulfonamides and trimethoprim vary with the geographical location of the patients in USA, Korea, Turkey, Europe, Austria, Greece, Portugal, Sweden, UK, Portugal and Sweden [30,32]. Previous studies gave diverse accounts from different parts of the world on the most commonly encountered Trimethoprim-resistant genes in the context of medical practice ( $s$ ull, sulll, $d h f r I, d h f r V$ and $d h f r X I I I)$. Their rates were found to be different from many findings in a number of UTIs studies from Syria, Lebanon, Denmark, The Netherlands, Korea, Australia, Spain, Portugal, France, Belgium, and Turkey which could be attributed to several factors [33]. In addition, tetracycline resistance is widespread among uropathogenic E. coli isolates from human infections in Iran [34] and the most common tet resistance mechanism in $E$. coli is the tetracycline efflux pumps, which exports the drug out of the cell one of which is the tet $A$ found in $95 \%$ of the MDR E. coli isolates from UTIs in Nigeria [35]. Of the 29 E. coli isolates specified in our study, a total of $\geq 16$ were MDR to penicillins, sulfonamides, cephalosporins, tetracyclines, and aminoglycosides which have attributed to the emergence and dissemination of AMR strains of $E$. coli [36,37], several other findings from this study are noteworthy in terms of their public health importance. One of which is the disturbing finding that, $96.5 \%$ (28/29) of the $E$. coli isolates were resistant to SXT. This drug combination is recommended for treating a range of human infections, including complicated UTI, acute uncomplicated cystitis, and pyelonephritis [38]. Virtually all SXT-resistant isolates from this study (27/29), however, were susceptible to ciprofloxacin which is an important antimicrobial for treating infections caused by sulpha-methoxazole-trimethoprim (SXT)-resistant $E$. coli. The emergence and dissemination of AMR in E. coli strains of serotype O111 isolated in the present investigation, could result in hindering the treatment of certain human UTI and gastrointestinal infections [36]. The variability in the frequencies of resistance genes between our results from the published articles on E. coli UTIs is not a country-to-country difference only, but rather, a country situation difference. AMR phenotype is a crude measure to adequately explain co-selection of antibiotic resistance genes since antimicrobial exposure does not appear to 
coselect for all genes encoding a given phenotype. For example, Rosengren et al. showed a close association of $d h f r I$ with sul1 and sul2 while $d h f r X I I I$ was not associated with any sul gene, meaning sulfonamide exposure selecting for resistance mediated by sull or sul2 would lead to greater abundance of $d h f r I$-mediated trimethoprim resistance but not $d h f r X I I I$-mediated trimethoprim resitance [39]. Exploring how AMR genes are associated with each other and antimicrobial exposure may explain some observed increase in sensitivity to certain antibiotics when others are used [39].

\section{Conclusion}

The possibility of dissimation of novel resistance patterns into the environmental echo system during participating in an MG requires cooperation between medical and health professions, veterinarians, farmers, food safety specialists and other experts, to monitor and control E. coli UTIs [40-42]. Therefore, haemolytic and antibiotic resistant $E$. coli strains are emerging pathogens and their molecular typing is useful for surveillance purposes. To the best of our knowledge, this is the first pilot study to characterize hemolytic and antibiotic-resistant $E$. coli in unorganized MGs in Egypt and worldwide [8]. Further investigations are required, concerning the effects of antibiotic-resistant strains in MGs on the natural ecosystem, and on selection of resistance and its impact on human health [8].

\section{Future perspective}

The continuous incidents of OGMGs or even UNORGMGs nationally throughout the year without effective control has worsened bacterial contamination and their resistome in the echo system. Therefore, a molecular surveillance system must be adopted for other Enterobactereacea to give an insight on the current and everchanging situation in the resistance prevalence and dissemination between organisms, and to correlate the isolates from the different ecological niches.

\section{Acknowledgements}

The authors extend their appreciation to the Deanship of Scientific Research at King Saud University for funding the work through the research group project No.: RGP-162.

\section{Financial \& competing interests disclosure}

This work was supported by the Deanship of Scientific Research at King Saud University for funding the work through the research group project No.: RGP-162. The authors have no other relevant affiliations or financial involvement with any organization or entity with a financial interest in or financial conflict with the subject matter or materials discussed in the manuscript apart from those disclosed.

No writing assistance was utilized in the production of this manuscript.

\section{Ethical conduct of research}

The patients were provided with written and verbal information on the study goal, methods, advantages and consequences of the study. Each patient's file was treated independently and confidentially, and only the data analyst had access to secured data and patients' information.

\section{Open access}

This work is licensed under the Attribution-NonCommercial-NoDerivatives 4.0 Unported License. To view a copy of this license, visit http://creativecommons.org/licenses/by-nc-nd/4.0/ 
Summary points

MGs could aggravate the problem of multidrug-resistant dissemination in Egypt

- The 29 Escherichia coli isolates were resistant to $46.7 \%$ of the tested antibiotics.

Virulence \& invasive capacity of the $E$. coli isolates

- The isolates were also able to produce cytopathic effects on the Vero and MDCK cells, and had $100 \%$ motility, embryo lethality, hemolytic activity and $100 \%$ CR affinity.

- The iss gene was detected with the highest prevalence in seropathotypes A, B2 and D (100\%).

- The eae, ibeA, iroN $\mathrm{N}_{E \text {.coli }}$ and kpsMT II genes were totally absent from the three phylogenetic groups.

- None of the iroN $\mathrm{N}_{E . c o l i}, k p s \mathrm{MT}$ II, ibeA and eae genes were detected in any of the $29 \mathrm{E}$. coli isolates.

Phenotypic antibiotic resistance profile

- The 29 isolates were $100 \%$ resistant to tetracycline, naldixic acid, ampicillin, trimethoprim, neomycin, oxytetracycline and erythromycin.

High prevalence of antibiotic-resistance genes

Four different antibiotic resistance genes combinations $(19 / 29,65.5 \%)$ were seen in the form of:

- Eight double $(8 / 29,27.6 \%)$ gene combinations: $(n=2 / 29(6.9 \%)$, dhfrl- $d h f r X I I I ; n=n=2 / 29(6.9 \%)$, dhfrl- sull, Trimethoprim + Sulphonamide), ( $n=4 / 29(13.8 \%)$, sull- sulll Sulphonamide).

- Seven triple $(7 / 29,24.1 \%)$ gene combinations: $(n=1(3.5 \%)$, tet $(A)$ - dhfrl- dhfrXIIl; $n=n=2 / 29(6.9 \%)$, dhfrl- sullsull, Trimethoprim + Sulphonamide; $\mathrm{n}=\mathrm{n}=2 / 29$ (6.9\%), dhfrl- dhfrXIII- sulll Trimethoprim + Sulphonamide; $\mathrm{n}=\mathrm{n}=2 / 29(6.9 \%)$, tet $(A)$ - dhfrl- sulll Tetracycline + Trimethoprim + Sulphonamide).

- Two quadruple $(2 / 29,6.9 \%)$ gene combinations: $(n=n=2 / 29(6.9 \%)$, dhfrl- dhfrXIII- sull-sulll Trimethoprim + Sulphonamide).

- Two pentadruple $(2 / 29,6.9 \%)$ gene combinations: $(n=n=2 / 29$ (6.9\%) tet (A)- dhfrl-dhfrXIII- sull-sullI Tetracycline + Trimethoprim + Sulphonamide).

Absence of resistance traits

- The trimethoprim dhfrV gene was not detected in any of the $29 \mathrm{E}$. coli isolates.

- Four isolates remained negative for tet (A)- dhfrl- dhfrXIII- sull-sullI.

Diversity in phylogenetic groups, sequence types \& pulsotypes

- Three phylogenetic groups (A, B2 and D) were recovered with the prevalence of group B2 (44.8\%).

- Our isolates showed typical identity (100\%) with E. coli plasmid pVM01, E.coli APEC-O1-plasmid-ColBM, E. coli plasmid-p300iro, E. coli iss-gene, E.coli isolate-Beijing1-iss, E. coli isolate-Xinda-iss, E. coli isolate-Tianda-iss, E. coli isolate-Beijing3-iss, E. coli isolate-Guizhou1-iss and E. coli isolate-E18-iss..

- The percentage of identity reached $98.4 \%$ with E.coli DNA-iss-plasmid.

- While the percentage of identity reached its lowest degree $95.2 \%$ with E. coli CFT073.

- From the phylogenetic analysis of the iss gene, we found that there are two groups: A and B.

- The B group was divided into subgroups B1 and B2, and subgroup B2 included three arms a, b and c.

- The majority of isolates fell within phylogenetic group B2, which belongs to the virulent pathotypes of $E$. coli.

Conclusion

- This is the first pilot study to characterize virulent antibiotic resistant $E$. coli in urinary tract infection (UTI) attending MGs in Egypt and globally.

- The variability in the frequencies of resistance genes between our results from the published articles on $E$. coli UTIs does not reflect a country-to-country difference only, but rather, a country situation difference.

- The possibility of dissimation of novel resistance patterns in the environmental echo system during participation in an MG requires cooperation between medical and health professions, veterinarians, farmers, food safety specialists and other experts, to monitor and control $E$. coli UTI.

\section{References}

1. World Health Organization. Public Health for Mass Gatherings: Key Considerations. World Health Organization, 20 Avenue Appia, 1211 Geneva 27, Switzerland (2015).

2. Government of Canada. activities and initiatives. Mass gatherings (large-scale events). https://travel.gc.ca/travelling/health-safety/mass-gatherings

3. Tam JS, Barbeschi M, Shapovalova N et al. Research agenda for mass gatherings: a call to action. Lancet Infect. Dis. 12, 231-239 (2012).

4. Centers for Disease Control and Prevention. Mass Gathering Preparedness - A Global Health Security Victory for All at World Cup in Brazil. Atlanta, GA, USA, 232-6348 (2014).

5. Elachola H, Gozzer E, Zhuo J et al. Mass gatherings: a one-stop opportunity to complement global disease surveillance. J. Health Spec. 4, 178-185 (2016).

6. Lee CV, Brunette GW, Gallagher NM. Travel to Mass Gatherings.Centers for Disease Control and Prevention Centers for Disease Control and Prevention. Atlanta, GA, USA, (2012). 
7. World Health Organization. Public Health For Mass Gatherings: Key Considerations. World Health Organization, Geneva, Switzerland (2016).

8. European Centre for Disease Prevention and Control. Potential risks to public health related to communicable diseases at the Olympics and Paralympics Games in Rio de Janeiro, Brazil (2016). Stockholm, Sweden (2016).

9. Al-Tawfiq JA, Memish ZA. Potential risk for drug resistance globalization at the Hajj. Clin. Microbiol. Infect. 21, 109-114 (2015).

10. Osman KM, Mustafa AM, Elhariri M et al. Identification of serotypes and virulence markers of Escherichia coli isolated from human stool and urine samples in Egypt. Indian J. Med. Microbiol. 30, 308-313 (2012).

11. Clinical and Laboratory Standards Institute. Performance Standards for Antimicrobial Susceptibility Testing 32(Suppl. 22) CLSI document M100-S22. Wayne, PA, USA (2012).

12. Nakao R, Ramstedt M, Wai SN et al. Enhanced Biofilm Formation by Escherichia coli LPS Mutants Defective in Hep Biosynthesis. PLoS ONE 7, e51241 (2012).

13. Clermont O, Bonacorsi S, Bingen E. Rapid and simple determination of the Escherichia coli phylogenetic groups. App. Environ. Microbiol. 66, 4555-4558 (2000).

14. Heininger A, Binder M, Schmidt S et al. PCR and blood culture for detection of Escherichia coli bacteremia in rats. J. Clin. Microbiol. 37, 2479-2482 (1999).

15. Janßen T, Schwarz C, Preikschat P et al. Virulence-associated genes in avian pathogenic Escherichia coli (APEC) isolated from internal organs of poultry having died from colibacillosis. Int. J. Med. Microbiol. 291, 371-378 (2001).

16. Ewers $\mathrm{C}, \mathrm{Li} \mathrm{G}$, Wilking $\mathrm{H}$ et al. Avian pathogenic, uropathogenic, and newborn meningitis-causing Escherichia coli: how closely related are they? Int. J. Med. Microbiol. 297, 163-176 (2007).

17. Johnson JR, Stell AL. Extended virulence genotypes of Escherichia coli strains from patients with urosepsis in relation to phylogeny and host compromise. J. Infect. Dis. 181, 261-272 (2000).

18. Wiles TJ, Kulesus RR, Mulvey MA. Origins and virulence mechanisms of uropathogenic Escherichia coli. Exp. Mol. Pathol. 85, 11-19 (2008).

19. Yaguchi K, Ogitani T, Osawa R et al. Virulence factors of avian pathogenic Escherichia coli strains isolated from chickens with colisepticemia in Japan. Avian Dis. 5, 656-662 (2007).

20. Maynard C, Bekal S, Sanschagrin F et al. Heterogeneity among virulence and antimicrobial resistance gene profiles of extraintestinal Escherichia coli isolates of animal and human origin. J. Clin. Microbiol. 42, 5444-5452 (2004).

21. Wharton M, Spiegel RA, Horan JM et al. A large outbreak of antibiotic-resistant shigellosis at a mass gathering. J. Infect. Dis. 162, 1324-1328 (1990).

22. World Health Organization. Communicable disease alert and response for mass gatherings: key considerations (2008). Publications of the World Health Organization can be obtained from WHO Press, World Health Organization, Geneva, Switzerland (2008).

23. Mokracka J, Koczura R, Jabłońska L et al. Phylogenetic groups, virulence genes and quinolone resistance of integron-bearing Escherichia coli strains isolated from a wastewater treatment plant. Antonie van Leeuwenhoek 99, 817-824 (2011).

24. Bashir S, Haque A, Sarwar Y et al. Virulence profile of different phylogenetic groups of locally isolated community acquired uropathogenic E. coli from Faisalabad region of Pakistan. Ann. Clin. Microbiol. Antimicrob. 11, 23 (2012).

25. Alizade H, Ghanbarpour R, Aflatoonian MR. Virulence genotyping of Escherichia coli isolates from diarrheic and urinary tract infections in relation to phylogeny in southeast of Iran. Trop. Biomed. 31, 174-182 (2014).

26. Lee S, Yu JK, Park K et al. Phylogenetic groups and virulence factors in pathogenic and commensal strains of Escherichia coli and their association with blaCTX-M. Ann. Clin. Lab. Sci. 40, 361-367 (2010).

27. Nandanwar N. Functional genotyping of extraintestinal pathogenic E.coli (ExPEC) belonging to the highly pathogenic Sequence type 95 reveals the zoonotic nature of human and avian strains. Inaugural-Dissertation To obtain the academic degree Doctor rerum naturalium (Dr. rer. nat.) Submitted to the Department of Biology, Chemistry and Pharmacy Of Freie University Berlin, (2014). https://d-nb.info/1049929845/34

28. Manges AR, Johnson JR, Foxman B et al. Widespread distribution of urinary tract infections caused by a multidrug-resistant Escherichia coli Clonal Group. N. Engl. J. Med. 345, 1007-1013 (2001).

29. Wester AL, Melby KK, Wyller TB et al. E. coli bacteremia strains - high diversity and associations with age-related clinical phenomena. Clin. Microbiol. 3, 140 (2014).

30. Mellata M. Human and avian extraintestinal pathogenic Escherichia coli: infections, zoonotic risks, and antibiotic resistance trends. Foodborne Pathog. Dis. 10, 916-932 (2013).

31. Abduzaimovic A, Aljicevic M, Rebic V et al. Antibiotic resistance in urinary isolates of Escherichia coli. Materia Socio-Medica. 28, 416-419 (2016).

32. Wiedemann B, Heisig A, Heisig P. Uncomplicated urinary tract infections and antibiotic resistance - epidemiological and mechanistic aspects. Antibiotics 3, 341-352 (2014). 
33. Al-Assil B, Mahfoud M, Hamzeh AR. First report on class 1 integrons and Trimethoprim-resistance genes from dfrA group in uropathogenic E. coli (UPEC) from the Aleppo area in Syria. Mob. Genet. Elements 3, e25204 (2013).

34. Gharajalar SN, Sofiani VH. Patterns of efflux pump genes among tetracycline resistance uropathogenic Escherichia coli isolates obtained from human urinary infections. Jundishapur J. Microbiol. e40884 (2017).

35. Igwe JC, Musa A, Olayinka BO et al. Tetracycline resistant genes in E. coli isolated from UTI and diarrhea patients in Zaria, Nigeria. Clin. Microbiol. 4, 225 (2015).

36. Schroeder CM, Meng J, Zhao S et al. Antimicrobial resistance of Escherichia coli O26, O103, O111, O128, and O145 from animals and humans. Emerg. Infect. Dis. 8, 1409-1414 (2002).

37. Doyle MP, Loneragan GH, Scott HM et al. Antimicrobial resistance: challenges and perspectives. Comp. Rev. Food Sci. Food Saf. 12, 234-248 (2013).

38. Karaca Y, Coplu N, Gozalan A et al. Co-trimoxazole and quinolone resistance in Escherichia coli isolated from urinary tract infections over the last 10 years. Int. J. Antimicrob. Agents 26, 75-77 (2005).

39. Rosengren LB, Waldner CL, Reid-Smith RJ. Associations between antimicrobial resistance phenotypes, antimicrobial resistance genes, and virulence genes of fecal Escherichia coli isolates from healthy grow-finish pigs. Appl. Environ. Microbiol. 75, 1373-1380 (2009).

40. Memish ZA. The Hajj: communicable disease alert and response for mass gatherings: key considerations. Geneva, World Health Organization (2008) www.who.int/csr/mass_gathering/en/index.html

41. Memish ZA. The Hajj: communicable and non-communicable health hazards and current guidance for pilgrims. Euro Surveill. 15(39), 19671 (2010)

42. AlNsour M, Fleischauer A. Public health considerations for mass gatherings in the Middle East and North Africa (MENA) region. Eastern Mediterranean Health J. 19, S42-S47 (2013). 